Closet of Curiosities when they died, and at last had resolved to give it unto me".

After the death of John, the husband (1662), acute trouble arose in regard to the collections, settled, however, by Lord Chancellor Clarendon, in 1664, in favour of Ashmole, who was to "have and enjoy" the collection of rarities. Ashmole was then living in a house next to the Tradescants.

After Ashmole had obtained possession of the repository there came a period (about 1677), when it was urgently necessary to assign its contents. There were also certain manuscripts and books thought worthy. It was no use to cast eyes towards Gresham College. It was therefore not unreasonable, he thought, to offer his possessions to Oxford, his alma mater, but conditionally on the erection of a building to house them. He had been much honoured there in 1669 as a "curioso and virtuoso". Certainly a bold proposition, all things considered; nevertheless, it was gratefully accepted. Thereafter, the Ashmolean building took shape and became the designated habitation, erected at the charge of the University, fulfilling, at least in some measure, Ashmole's original hopes.* The foundation stone was laid on Thursday, May 15, 1679, and the Museum was opened on May 21, 1683. The Duke and Duchess of York, and their retinue, attended. There was feasting and jollity, and Ashmole (with whom was Mrs. Ashmole) was applauded and favoured to the top of his bent. Dr. Plot, the first custodian, gave a "sette speech". After the chief ceremony, the company went down to a newly fitted chemical "elaboratorie", where they witnessed some experiments, which are recorded as having given great satisfaction. A revival of the activities of the philosophers forming the Philosophical Society of Oxford, the original members of which had close contact with the Royal Society in London, occurring, their meetings were held in the Ashmolean for some time, and were both profitable and inspiring.

Space will not allow reference to the vicissitudes which later waited upon the Old Ashmolean, ending in neglect and disrepair. Dr. R. T. Gunther has dealt with these points, and of a brighter period, bringing in its train appreciation of new uses and recognition of the historic past.

* On January 26, 1678/9, a fire in the Middle Temple destroved Ashmole's library, and many curios, in all probability, destined for Oxford.

\title{
Obituary
}

\section{The Duke of THE ABRuzzI}

$\mathrm{F}^{\mathrm{E}}$ EW men have led lives so full of interest and accomplishment as Prince Luigi of Savoy, Duke of the Abruzzi, who died on March 18 at the age of sixty years. Mariner, explorer, admiral, colonist, and man of science, he exhibited vision and initiative in every field of his numerous activities, and, by sheer tenacity of purpose, achieved success in the most arduous of ventures.

The Duke's connexion with the Italian navy commenced in 1879 when, at the age of six, he entered the service as cabin boy. From 1884 until 1889 he was occupied in study at the Royal Naval Academy. In those days Italy was not very well known in foreign countries and, to remedy this, the ships of the navy were sent on missionary work to distant lands and even round the whole world. Such patriotic propaganda found an enthusiastic supporter in the young Prince who, in the Amerigo Vespucci, the Volturno, and the Cristoforo Colombo, took part in several long voyages, ultimately attaining the rank of lieutenant. His first important naval command, in 1902, was that of the cruiser Liguria, in which he made a tour of the world lasting eighteen months. Further promotions followed, and the Duke commanded a squadron during the Italo-Turkish war of 1911-12, and was appointed to the supreme command of the Italian navy during the War.

As a traveller and explorer, the services of the Duke of the Abruzzi to science and to his country were outstanding. His early education in this direction was acquired during his teens in the Alps under the guidance of the well-known alpinist, Francesco Gonella. The Alps were also the scene of many of his later ascents and before he reached the age of thirty he had climbed, in some cases during the winter, all the most difficult Alpine peaks, some of which had not been previously conquered.

During his world-tour of 1894-96, the Duke saw the Himalayas for the first time and on his return to Italy he made preparations for an ascent of Nanga Parbat $(8,115$ metres $)$. This expedition was, however, frustrated owing to an outbreak of plague and famine, which decimated the Punjab. The objective was therefore changed to a peak very different in character, Mount St. Elias in Alaska. Unlike Nanga Parbat, with a lower snow limit at about 5,000 metres, Mount St. Elias is covered from base to summit with glaciers, which debouch into the waters of the Pacific. The mountain-which is visible from the sea at a distance of 200 miles and has been known to navigators since the beginning of the eighteenth century-and its immediate surroundings were at that time completely unexplored. The expedition, consisting of the Duke and five companions, together with four Alpine guides, left Italy in May, 1897, and was joined at Yakutat Bay by ten American porters. Three days were occupied in crossing the wide plateau of the Malaspina glacier, and four laborious weeks in traversing the Seward, Agassiz, and Newton glaciers, fissured by enormous crevasses. Just over ten weeks after leaving Italy, the party camped beyond the Newton glacier at the foot of the great pyramidal mass of the mountain, and less than three days later reached the summit without casualty.

The observations made gave the altitude of 
Mount St. Elias as 5,514 metres, in good agreement with the value $(5,516$ metres) calculated by Russell who, in 1891, reached a col situated at a height of 3,745 metres. Two unknown snowy peaks, observed in the west, were named Lucania and Bona, these being identified topographically and measured sixteen years later by American observers. A series of meteorological and glaciological observations was made, and collections of the minerals and minute fauna of the glaciers, and the first complete series of views of the St. Elias group were secured.

In the summer of 1898 the Duke visited Spitsbergen and in the following winter made an excursion by sleigh into Central Siberia. Preparations were then made-quietly, indeed almost secretly-for a north polar expedition. It was decided not to follow the plan adopted by Nansen in his earlier attempt, but to proceed by ship as far north as the currents allowed and then set out on foot. A Norwegian sealing vessel, re-christened the Stella Polaris, was acquired and the party of eleven Italians, with a Norwegian crew of nine, sailed in July 1899 from Archangel, where the sleigh-dogs had been shipped. Franz Josef Land was reached in three weeks' time and the ship proceeded through the archipelago to cast anchor off Prince Rudolph Island (lat. $82^{\circ} 4^{\prime} \mathrm{N}$.), the most northerly island of the group. The ship narrowly escaped destruction in the ice, but was ultimately brought into a position of safety, and winter quarters were constructed on the island. During one of the trial sledge trips, the Duke was attacked by frost-bite, followed by gangrene, which necessitated the amputation of two fingers. It was not until about four months later that the weather allowed of the dispatch of the sleigh party. This was divided into three groups, to return at intervals. The first group of three, under Lieut. Querini, never came back, but Capt. Cagni's group, who were absent from the camp for 104 days, reached lat. $86^{\circ} 34^{\prime} \mathrm{N}$., thus surpassing Nansen's record. In spite of the many difficulties encountered, the expedition was away only fourteen months, at that time the shortest period for a polar expedition.

Other expeditions organised by the Duke were those to Ruwenzori, in Central Africa, in 1906, when twelve peaks, all exceeding 4,600 metres, were ascended, measured and mapped; to the Karakoram Himalayas in 1909, when Bride Peak was climbed to a height of 7,500 metres (the highest altitude reached up to that time), the attempt to cover the remaining 150 metres having to be abandoned; and to the sources of the Webi Shebeli River, which flows through Ethiopia and Somaliland. On all these expeditions much valuable information of interest, not merely to geographers, but also to the whole scientific world, was collected and published. Their uniform success was due to the minute care taken in the preliminary preparations and, particularly, to the enthusiasm which the Duke showed and imparted to every one of his companions in every exploit he undertook.
The Italian Mission to the Abyssinian court in 1927 was led by the Duke, who later paid a second visit to the Webi Shebeli River and surveyed large areas in Abyssinia. Somaliland, where he had a large farm, claimed a good deal of his attention, and it was to his work on irrigation and on improvements in other directions that the opening up of this country was largely due.

Born in Madrid on January 29, 1873, shortly before the abdication from the Spanish throne of his father, Duke Amedeo of Aosta, brother to King Humbert of Italy, he passed away, after a life of ceaseless activity, in Somaliland, to the colonisation of which so much of his energy was devoted.

\section{Dr. Julius Schmidt}

WE regret to learn from the Chemiker-Zeitung of the death of Dr. Julius Schmidt, extra-ordinary professor of organic chemistry at the Technische Hochschule in Stuttgart and director of the Chemistry Laboratory at the Höhere Maschinenbauschule in Esslingen, aged sixty-one years. A native of Baiersdorf in Bavaria, Schmidt studied under Knorr at the University of Jena and graduated in 1894. In 1900 he was appointed lecturer in organic chemistry at Stuttgart, where he carried out numerous investigations in the field of organic chemistry. His researches dealt particularly with nitroso-compounds, oximes and quinones, and with derivatives of phenanthrene and fluorene. He was also the author of numerous books and pamphlets on alkaloids, quinones, nitroso-compounds, organic magnesium compounds and pyrazoles. He also published a handbook of organic chemistry, which has been translated into English, and a yearbook of organic chemistry.

We regret to announce the following deaths:-

Prof. Victor Goldschmidt, honorary professor of mineralogy in the University of Heidelberg, on May 8, aged eighty years.

Dr. William H. Holmes, formerly chief of the Bureau of American Ethnology and director of the National Gallery of Art, Washington, distinguished as a geologist, and a pioneer in field work in the archæology of North and Central America, on April 21, at the age of eighty-six years, at Royal Oak, Michigan, following on a paralytic stroke.

Dr. Leonard Huxley, editor of the Cornhill Magazine, author of "Life of Huxley", "Life of Sir Joseph Hooker", "Thomas Henry Huxley, a Character Sketch" and "Charles Darwin", on May 3 , aged seventy-two years.

Mr. John Mackereth, a deputy conservator in the Indian Forest Service, on May 5, aged thirtyfour years.

Prof. J. T. J. Morrison, emeritus professor of forensic medicine and toxicology in the University of Birmingham, on May 10, aged seventy-six years. 